\title{
PEMBERIAN LATIHAN AEROBIK UNTUK MENINGKATKAN KAPASITAS SISTEM ENERGI PADA ANAK SEKOLAH DASAR
}

\author{
Bintoro Widodo
}

Staf Pengajar pada PGMI Fakultas Tarbiyah UIN Malang

\begin{abstract}
Providing energy on human being is formed in a system, called as energy system. Energy system on human being is provided in some kinds, one of them is aerobic system (aerobic system capacity) and anaerobic system (anaerobic system capacity). To increase energy system on the body, so it requires a regular exercise. The exercise that we does has purpose to increase our energy provision as maximum as possible, whether it is done through effort to increase aerobic capacity system or effort to increase anaerobic capacity system. Aerobic system is a work done regularly as long as possible, a muscle work that is general in nature in aerobic condition, whereas anaerobic capacity is a work that make us able to do regularly as long as possible, a muscle work that is general in nature in anaerobic condition. The effort to increase energy system in aerobic exercise on children is an effort to create qualified human being resource.
\end{abstract}

Keyword: aerobic exercise, energy capacity system,

\section{A Pendahuluan}

Untuk dapat mencapai sasaran manusia Indonesia yang mempunyai kemampuan fisik yang baik, harus diawali dengan peningkatan kesegaran jasmani mulai dari pendidikan anak sekolah dasar sampai pada pendidikan sekolah lanjut. Dari hasil penelitian di ketahui bahwa status kesegaran jasmani anak usia sekolah mulai dari tingkat pendidikan sekolah dasar (SD) sampai tingkat pendidikan SLTA di Indonesia pada umumnya ada dalam katagori rendah dan sedang, bila di bandingkan dengan nilai standart kesegaran jasmani menurut Asian Committee on the Standardization of Physical Fitnes Test (ACSPFT) (Kuntaraf, 1985). Salah satu faktor yang bisa terjadi adalah kurangnya usaha peningkatan kesegaran jasmani yang tidak di imbangi dengan mekanisme kebutuhan energi untuk bergerak khususnya pada masa anak-anak atau usia anak sekolah dasar. Kebutuhan energi bagi anak-anak menjadi hal yang utama yang perlu diperhatikan bagi seorang guru penjas. Karena anak-anak sekolah dasar adalah anak-anak dalam proses perkembangan. Seorang guru penjas dapat mengidentifikasi secara jelas terhadap kualitas dan bentuk aktivitas kesegaran jasmani pada perkembangan anak secara normal dengan melalui aktivitas olahraga. Apabila pada usia anak sekolah 
dasar pendidikan jasmani dapat di penuhi dengan baik, maka akan berdampak positif pada perkembangan-perkembangan selanjutnya.

Salah satu faktor usaha peningkatan kesegaran jasmani adalah dengan latihan atau aktivitas olahraga. Latihan merupakan aktivitas olahraga yang dilakukan secara sistematis dalam waktu yang lama, ditingkatkan secara progresif dan mengarah kepada cici-ciri fungsi fisiologis dan psikologis manusia untuk mencapai sasaran yang di inginkan (Bompa, 1994). Dalam melakukan suatu latihan atau aktivitas olahraga, tidak lepas dari perlunya kebutuhan energi yang kita pakai. Kebutuhan energi tersebut dapat kita peroleh melalui suatu penyediaan sistem energi dalam tubuh. Semua penyediaan energi dalam tubuh dapat terbentuk melalui suatu sistem yaitu sistem aerobik dan sistem anaerobik. Kapasitas sistem aerobik digambarkan sebagai kemampuan jantung dan paru-paru untuk memasok oksigen dalam darah serta memompakan keseluruh tubuh yang bekerja dalam waktu atau durasi lebih dari 10 menit seperti lari 1500 meter, lari-jalan 600 yard (run-walk test 548,5 meter), marathon dan sebagainnya. Sedangkan kapasitas sistem anaerobik digambarkan sebagai kemampuan energi yang melibatkan kontraksi otot dalam keadaan anaerobik dengan aktifitas tidak lebih dari 1 menit lamanya, seperti lari 200 meter, 400 meter, dan 50 meter (McArdle, 1994).

Prinsip latihan fisik pada umumnya akan meningkatkan sistem energi sesuai bentuk latihan yang di lakukan. Pada latihan fisik yang dilakukan secara aerobik maka akan meningkatkan kapasitas sistem energi aerobic dalam tubuh, begitu pula sebaliknya pada latihan fisik secara anaerobik akan juga meningkatkan kapasitas sistem anaerobik. Pada masa anak-anak terdapat satu ke satuan sistem energi yang berperan dalam kegiatan fisiknya (Prasad, 1995). Jika ditinjau dari teori tersebut tentunya latihan fisik secara aerobik dan latihan fisik secara anaerobik akan samasama meningkatkan kapasitas aerobik maupun kapasitas anaerobik. Fakta diatas menjadi dasar bagi seorang guru pendidikan jasmani bahwa apapun peningkatan kapasitas sistem aerobik dapat meningkat melaui latihan yang bersifat aerobik atau latihan yang bersifat anaerobik. Demikian juga dengan perkembangan anak usia sekolah dasar, mereka akan memiliki kemampuan kesegaran jasmani yang baik sesuai dengan tingkat perkembangannya.

\section{B. Sistem Energi}

Energi yang digunakan dalam tubuh untuk melakukan aktivitas berasal dari makanan yang kita makan, energi tersebut mengalami perubahan dalam tubuh yaitu dari energi kimia menjadi energi mekanik. Kebutuhan energi tubuh merupakan hal yang penting untuk di perhatikan bagi setiap manusia maupun pada masa perkembangan anak-anak. Sebagian besar dari energi akan digunakan untuk kontraksi otot-otot untuk bergerak, untuk mempertahankan hidup kita seperti mengalirkan darah, 
bernafas, pembuatan enzim dan lain-lain (Soekarman, 1987:23). Sistem energi menjadi salah satu pedoman bagi setiap atlit, pelatih dan guru penjas dalam menentukan program latihan. Prinsip dasar dalam setiap program latihan adalah mengetahui sistem energi yang utama untuk digunakan atau lebih dikenal dengan sistem energi predominan (Fox, 1993:326). Dengan melalui prigram latihan yang benar sistem energi utama dapat ditingkatkan sesuai dengan kebutuhan masing-masing olahragawan sesuai sistem energi yang diperlukan.

Lamb (1984:119) mengutarakan, energi adalah kapasitas untuk melakukan kegiatan. Bila kegiatan meningkat energi yang diperlukan juga akan meningkat. Energi yang kita perlukan bisa diperoleh melalui sistem aerobik atau sistem anaerobik. Energi yang diperoleh melalui sistem aerobik berasal dari oksidasi karbohidrat dan lemak dengan penggunaan oksigen. Sedangkan energi yang diperoleh melalui sistem anaerobik berasal dari ATP yang dapat dibentuk kembali oleh PC. Pada setiap aktivitas atau olahraga yang kita lakukan tentu memiliki cirri-ciri tertentu dalam pemenuhan kebutuhan energi para pelakunya. Pada olahraga yang memiliki durasi yang lama dan konstan seperti lari jarak jauh atau bersepeda maka sistem energi aerobik sangat berperan sekali. Untuk olahraga yang tidak lebih dari 1 menit seperti lari 50 meter atau lari 100 meter maka sistem energi anaerobik sangat berperan sekali. Sedangkan olahraga yang memiliki ritme permainan bergantian waktu dan kondisi permaianan seperti permainan basket, bola voli menggunakan perpaduan antara kedua sistem energi tersebut. Dengan adanya aktivitas olahraga yang kita lakukan, maka kita dapat menggolongkan sistem energi mana yang berperan terhadap aktivitas olahraga kita.

Sistem energi menjadi perhatian yang utama bagi seorang pelatih atau seorang guru penjas karena mereka sama-sama memiliki anak didik yang di bina menjadi seorang yang dapat diandalkan dalam bidang olahraga. Untuk anak sekolah dasar energi menjadi bagian terpenting dalam proses membantu pertumbuhan dan perkembanga geraknya serta menjadi kebutuhan fisiologis dari tahap pembentukan. Dengan aktivitasnya yang membutuhkan gerak, maka anak sekolah dasar menjadi anak yang memiliki psikomotor yang dapat diandalkan.

\section{Kapasitas Sistem Aerobik}

Kapasitas sistem aerobik adalah suatu kemampuan tubuh dalam memenuhi kebutuhan energi untuk melaksanakan kerja yang bersifat aerobik. Kerja aerobik dilaksanakan dalam suatu kondisi dimana kebutuhan akan oksigen sangat diperlukan untuk melaksanakan aktivitas yang sedang dilakuakan. Ciri-ciri aktivitas yang bersifat aerobik adalah lari jarak jauh seperti lari 800 meter, 1500 meter atau aktivitas yang memerlukan waktu lebih dari 1 menit. Cooper (1982:207) menjelaskan bahwa latihan aerobik menunjukan pada kegiatan yang memerlukan 
oksigen dalam waktu yang panjang dan kebutuhan tersebut ada pada tubuh yang memerlukan pengembangan kapasitas mengambil oksigen. Untuk memenuhi kebutuhan energi secara aerobik lemak sebagai sumber energi utama dalam sel otot harus di tingkatkan. Brooks (1995) mengemukakan bahwa sistem aerobik meliputi oksidasi karbohidrat dan lemak sebagai sumber energi utama dan diproses secara aerobik. Latihan aerobik yang dilakukan secara teratur akan menghasilkan perubahanperubahan pada sistem kerja tubuh seperti sistem paru-paru, jantung dan pembuluh darah. Latihan aerobik termasuk aktivitas yang memerlukan transport oksigen sehingga kapasitas fungsional sistem ini dapat berkembang. Kapasitas sistem aerobik adalah kapasitas yang menggunakan energi yang berasal dari pembakaran oksigen yang dipertahankan dalam jangka waktu yang lama (soekarman, 1991:16).

Jenis latihan aerobik apabila dijalankan dengan benar dan teratur, akan banyak sekali pengaruhnya terhadap perkembangan tubuh manusia. Perubahan akibat latihan aerobik meliputi peningkatan oksidasi karbohidrat, peningkatan oksidasi lemak dan peningkatan mioglobin dalam otot. Kapasitas sistem aerobik meliputi penggunaan energi berasal dari kebutuhan akan oksigen.

\section{Kapasitas Sistem Anaerobik}

Kapasitas sistem anaerobik adalah suatu kapasitas dalam melaksanakan aktivitas secara terus menerus dalam kondisi anaerobik. Ciri-ciri aktivitas yang bersifat anaerobik adalah lari cepat/jarak pendek, angkat besi, tolak peluru atau aktivitas yang tidak memerlukan waktu lebih dari 1 menit. Kapasitas sistem anaerobik berlangsung dalam jangka waktu pendek, karena kondisi yang bekerja dalam penyediaan energinya adalah ATP dan PC (Adenasin Tri Phospahat dan phospho creatin).

Untuk meningkatkan kapasitas anaerobik perlu ditingkatkan persediaan ATP-PC dalam tubuh. Pate (1984:222) menerangkan bahwa pelepasan energi yang terjadi secara anaerobik (tanpa oksigen) merupakan pelepasan energi untuk jangka waktu yang singkat. Prinsip latihan yang harus diperhatikan adalah latihan interval atau berulang-ulang. Misalnya seorang pelari 800 meter ingin mencoba untuk mencatat waktu 2 menit dalam kejuaraan 800 meter, maka sebagian besar dalam waktu yang dipergunakan untuk latihan harus berada dalam rentang target 2 menit atau lebih cepat, yaitu atlet harus lari dengan berulang-ulang dalam jarak 100 meter dengan kecepatan kurang dari 15 detik. Untuk 200 meter dalam waktu 30 detik dan untuk 400 meter dalam waktu 60 detik atau lebih cepat. Dalam latihan interval akan terbentuk sebanyak mungkin enzim yang terlibat didalam produksi sistem anaerobik. Kapasitas sistem anaerobik meliputi penggunaan energi berasal dari ATP-PC dan asam laktak. 


\section{E. Latihan}

\section{a. Pengertian Latihan}

Latihan bila diterjemahkan dalam bahasa Inggris berasal darikata exercise atau training. Kent (1994) mendifinisikan training adalah suatu program latihan untuk membantu atlit dalam belajar keterampilan, memperbaiki kesegaran jasmani dan menyiapkan atlit untuk berkompetisi. Fox, (1993) mendifinisikan exercise yaitu gerakan atau aktivitas manusia yang melibatkan penggunaan kelompok otot-otot besar dan untuk kelompok-kelompak kecil relative gerakannya. Yang termasuk exercise adalah jogging, swimming, dan lain-lain.

Salah satu tujuan melakukan latihan adalah upaya meningkatkan kondisi fisik secara menyeluruh. Bompa (1994:3) menjelaskan bahwa latihan merupakan suatu kegiatan olahraga yang sistematis dalam waktu yang panjang dan ditingkatkan secara bertahap. Latihan harus ditekankan pada komponen-komponen fisik seperti daya tahan, kekuatan, kelincahan, kecepatan, kelentukan dan faktor-faktor lain yang mengembangkan fisik secara menyeluruh.

Prinsip-prinsip latihan yang harus diperhatikan adalah :

1. latihan harus spesifik, latihan harus bersifat khusus sesuai dengan kebutuhan olahragawan

2. Sistem energi predominan, latihan yang dilakukan harus mengetahui sistem energi mana yang paling dominant pada setiap latihan.

3. prinsip overload, prinsip latihan harus ada peningkatan beban secara bertahap

Anak-anak usia sekolah dasar pada umumnya senang akan bermain dan bergerak. Banyak sekali aktivitas fisik yang mereka lakukan dan ini menjadi kebutuhan bagi mereka. Salah satu faktor peningkatan fisik dilakukan dengan latihan atau aktifitas olahraga secara sistematis dan dalam waktu yang lama. Kegiatan fisik apabila dilakukan secara teratur, dalam ukuran yang tepat dan dalam waktu yang seimbang dapat menimbulkan adaptasi fisiologis organ-organ tubuh, sehingga tubuh dapat menerima beban yang lebih beratserta organ-organ tubuh dapat bekerja lebih efisien (Fox,1993). Untuk bisa melakukan kegiatan olahraga dengan teratur dan terarah, maka perlu adanya suatu program yang disebut dengan program latihan.

Fox (1993) mengemukakan bahwa ada empat factor yang harus diperhatikan dalam program latihan, yaitu:

1. frekuensi latihan: adalah waktu latihan dalam satu minggu yaitu antara tiga sampai lima kali dalam seminggu.

2. intensitas latihan: Latihan yang dilaksanakan terus menerus dengan menentukan waktu dan beban latihan yang akan di kehendaki 
3. Lamannya latihan: tergantung dari intensitas latihan sampai pada pencapaian hasil yang diharapkan

4. Jenis kegiatan: harus memiliki cirri-ciri pada sasaran pencapaian hasil yang diharapkan dengan memperhatikan kerja otot yang dilatih, memiliki ritme latihan yang teratur dan latihan yang mudah dan tetap

\section{b. Latihan aerobik}

Latihan aerobik lebih berkaitan dengan daya tahan tubuh kita dalam melakukan aktivitas olahraga. Cooper (1982) menjelaskan bahwa latihan aerobik adalah aktivitas olahraga yang menggunakan kapasitas energi aerobik untuk beraktivitas dalam waktu yang panjang. Prinsip latihan pada latihan aerobik adalah memberikan beban ringan dan dilaksanakan dalam waktu yang lama, energi yang digunakan berasal dari pemenuhan kebutuhan akan oksigen. Astrand (1986:334) menjelaskan bahwa latihan teratur yang dilakukan tiga kali latihan dalam seminggu dengan durasi 30 menit, pada umumnya akan menghasilkan peningkatan kapasitas sistem aerobik maksimal rata-rata 10\% - 20\%. Sedangkan Fox (1993:291) menjelaskan bahwa intensitas latihan pada umumnya ditentukan dengan monitor denyut jantung, adalah suatu cara tidak langsung untuk menkasir penggunaan oksigen oleh tubuh. McArdle (1981:274) menjelaskan bahwa sebagai kekuatan umum kapasitas sistem aerobik dapat ditingkatkan, jika intensitas latihan yang dilakukan meningkatk sampai pada denyut jantung mencapai $70 \%$ dari denyut jantung maksimal. Untuk itu maka latihan peningkatan kapasitas sistem aerobik dapat menggunakan pedoman dari denyut jantung setiap orang yang akan berlatih.

Janssen (1987:28) menyatakan bahwa denyut jantung dipengaruhi oleh umur, maka untuk menentukan denyut jantung maksimal digunakan rumus: 220-umur. Fox (1993:431) mengemukakan juga bahwa denyut jantung maksimal tidak dapat ditentukan secara langsung, tetapi berdasarkan gerak tubuh sampai pada pencapaian denyut nadi secara maksimal. Kalau kita menentukan intensitas latihan aerobic dengan menggunakan rumus 220-umur, maka intensitas latihan adalah $70 \%$ dari denyut jantung maksimal. Misalnya usia 20 maka denyut jantung maksimal adalah $220-20=200$, kemudian di akumulasi $70 \%$ dari denyut jantung maksimal dan berkisar antara 130 - 140 denyut permenit. Latihan aerobik dengan menggunakan intensitas latihan $70 \%$ dari denyut jantung maksimal akan memberikan kontribusi terhadap pemenuhan kebutuhan kapasita sistem energi aerobik. Dengan memperhatikan prinsip-prinsip latihan aerobik seperti frekuensi latihan, lama latihan dan intensiatas latihan yang rendah. 
c. Latihan aerobik dengan latihan naik turun bangku

Latihan naik turun bangku adalah salah satu cara latihan untuk meningkatkan kapasitas sistem energi aerobik. Dengan latihan naik turun bangku peningkatan kapasitas sistem energi aerobik dapat lebih muda kita peroleh, dengan memperhatikan prinsip-prinsip pada latihan aerobik. Karena prinsip latihan ini mudah dan dapat dilakukan oleh semua orang mulai dari anak-anak hingga orang dewasa. Latihan naik turun bangku menggunakan bangku yang panjang (bangku swedia) dengan ukuran serta tingginya tergantung dari bentuk latihan dan orang yang dilatih. Johnson (1986:156) menjelaskan tentang tinggi bangku yang digunakan adalah 12 inci $(30,1 \mathrm{~cm})$ untuk anak laki-laki usia 9-12 tahun dan yang lain 20 inci $(50,8 \mathrm{~cm})$ untuk orang dewasa. Setiap panjang bangku dapat memuat $3-4$ anak sekolah dasar.

Prinsip latihan naik turun bangku ini adalah melangkahkan kaki kanan ke atas bangku kemudian di susul dengan kaki kiri melangkah ke atas bangku hingga kedua kaki sejajar diatas bangku, kemudian kaki kanan turun kebawah dan disusul kembali oleh kaki kiri, demikian gerakan ini dilakukan secara terus menerus. A pabila di lekukan dengan prinsip dasar latihan aerobik maka latihan aerobik untuk anak usia 9-10 tahun dengan latihan naik turun bangku adalah:

1. Jenis latihan : naik turun bangku

2. Beban latihan : 25 kali gerakan naik turun bangku permenit selama

3. Set 10 menit setiap kali latihan

4. frekuensi : 3 kali dalam seminggu (senin, rabu dan jum'at)

5. Lama latihan : 6 minggu

6. Intensitas latihan: $70 \%$ denyut jantung maksimal (latihan bersifat aerobik)

Sebagai bahan acuan untuk mengetahui adanya peningkatan dari hasil latihan, alangkah baiknya di lakukan pre test terlebih dahulu. Untuk meningkatkan kapasitas sistem aerobik maka dapat dilakukan tes dengan lari 2,4 km. Hasil pretes itu di catat dan di simpan sebagai pedoman nanti pada saat pemberian post test setelah malakukan program latihan yang di berikan. Setelah melakukan latihan setelah 6 minggu maka di berikan lagi tes lari 2,4 km, apakah ada peningkatan waktu lari setelah di berikan latihan selama 6 minggu. Apabila ada peningkatan, maka latihan yang di berikan berhasil, dan apabila terjadi penurunan maka dapat di simpulkan apakah program yang di berikan kurang tepat atau kondisi anak tersebut tidak fit atau sebagainnya. Ini menjadi bahan evaluasi dalam menentukan program latihan selanjutnya. 


\section{F. Kesimpulan}

Pemberian latihan aerobik yang menggunakan model latihan naik turun bangku dengan mengutamakan prinsip kerja energi aerobik dapat memberikan gambaran model-model latihan untuk meningkatkan sistem energi pada anak-anak usia sekolah dasar. Peningkatan kapasitas system energi pada anak-anak (childhood) mulai akan berbeda pada saat akan menginjak usia dewasa (Adolesance). Perbedaan tersebut meliputi tingkat kondisi perkembangan anatomi masing-masing individu dan peranan sistem energi pada masa anak-anak.

Dengan berpedoman pada prinsip-prinsil model latihan aerobik, kemampuan kapasitas sistem eneri pada masa anak-anak dapat ditingkatkan secara signifikan, yang berpedoman pada prinsip-prinsil latihan seperti intensitas latihan, frekuensi latihan, lama latihan dan beban latihan. Seorang guru penjas harus mengerti bagaimana kita dapat menerapkan latihan yang sesuai dengan apa yang di targetkan. Apabila akan meningkatkan kapasitas sistem energi dengan menggunakan latihan aerobik, maka seorang guru penjas harus bisa menentukan program latihan yang bersifat aerobik, demikian juga dengan prinsip-prinsil latihan yang laian, mereka memiliki cirri khas masing-masing.

\section{G. Daftar Pustaka}

Astrand PO, dan Rodahl, K., 1986 Textbook of work Physiology, Physiological Bases of exercise, $3^{\text {td }}$ ed, New York:McGraw-Hill Book Company. Pp.119-132.

Bompa TO, 1994. Theory and Methodology of Training, Dubuque Iowa: Kendall/Hunt Publishing, Company. Pp. 290-294.

Brooks GA, and Fahey TD, 1984, Exercise Physiology; Human Bioenergetic and Its Aplications, 1nded, John Willey and Sons Inc., New York, pp. 73$79,413$.

Cooper KH, 1982. The Aerobic Program for Total Wellbeig, New York: M.Evans \&Co, Inc. pp 203-211.

Corbin B, 1980. A Text of Motor Development, 2 nded. Iowa, Brown Company Publisher, Dubuque, pp.13-31.

Fox EL, Bowers RW, and Foss ML, 1993, The Physiology Basis of Phisical education and Athletics, Iowa: Brown and Benchmark Publishers. Pp 320-342.

Janssen PGJM, 1987. Training lactate Pulse Rate, New York: Polar Electro Oy. Pp31-42.

Johnson BL, dan Nelson JK., 1986. Practical Measurement for Evaluation in Physical Education. 4tded, New York: Macmillan Publishing company, pp 152-164. 
Kuntaraf, 1989. Kesehatan Olahraga, Jakarta, Gramedia hal 345-346.

Lamb RD, 1984. Physiology of Exercise. 2 nded, New York: Macmillan Publishing Company. Pp 118-229.

McArdle WD., dan Katch FI, 1986. Exercise Physiology: Energy Nutrilionand Human Performance. Philadelphia. Pp 45-76.

Pate RR 1984. Scintific Foundations of Coaching: Philadelphia, Sounders Collage Publhising. Pp 177-182.

Prasad N, 1995. Relationship Between Aerobic and Anaerobic Exercise Capacitiesin Pre-pubertal Children, Medichine and Science in Sports and Exercise.

Soekarman R, 1991. Energi dan Sistem Energi predominan Pada Olahraga, Jakarta Inti Idayu Press Hal 21-25.

Soekarman R, 1987. Dasar Olahraga Untuk Pembina, Pelatih Dan Atlit, Jakarta: Inti idayu Press Hal11-18. 